FACTA UNIVERSITATIS

Series: Law and Politics Vol. 15, N 3, 2017, pp. 253 - 263

https://doi.org/10.22190/FULP1703253T

Original Scientific Article

\title{
TRAFFICKING IN PSYCHOACTIVE SUBSTANCES
}

UDC 343.241:343.575](497.11 Niš)

\section{Marina Trenkić}

Higher Court in Niš, Republic of Serbia

\begin{abstract}
The paper presents the results of the empirical research carried out at the Higher Court in Niš in the period from 01/01/2013 to 01/01/2016. On the basis of the statistical data collected on narcotics-related crimes, the paper shows how many final judgments were imposed for each of these criminal offences in the observed period. Most commonly, these crimes are directly committed by young men, whereas women are mostly complicit in these criminal offences. Given the fact that the number of criminal offences related to narcotics increases year after year, it may be concluded that the abuse of psychoactive substances represents an unsolvable problem. The research was aimed at determining the number of judgments rendered for the criminal offences of complicity, as well as the most commonly trafficked narcotics, where marijuana seems to prevail. The research was also aimed at examining the penal policy pertaining to criminal offences related to narcotics, including both criminal sanctions and safety measures imposed on the perpetrators of these criminal offences.
\end{abstract}

Key words: narcotics, complicit women, complicity, penalty, safety measures, penal policy

\section{INTRODUCTION}

Psychoactive substance abuse is nowadays a global problem in all societies and it has existed as such in all civilizations throughout history. The development of human civilization has led to uncontrolled drug abuse which devastates human personality, both physically and mentally. Drug abuse, narcotics addiction or toxicomania are regarded as a social evil that the countries of Southeastern Europe have been facing particularly in recent decades.

In the modern world, major social changes occur and unexpected relations are established in different socio-economic environments. Drug abuse causes great detrimental consequences to health of the entire nation, especially the young population. Families have become unstable and disharmonic, which has further changed the demographic characteristics of addicts, who now come from all socio-economic layers of society. Younger generations are now exposed

Received March $6^{\text {th }}, 2017 /$ Accepted June $22^{\text {nd }}, 2017$

Corresponding author: Marina Trenkić, LL.M, Trainee-volunteer

Higher Court in Niš, Republic of Serbia

E-mail: trenkic.marina@gmail.com 
to new synthetic narcotics, which are significantly cheaper but not less harmful. The most widely used narcotics in this region are cannabis, heroin, ecstasy and amphetamines, whose detrimental effects are nowadays significantly diminished by the increasing use of cocaine.

On the other hand, the profit that organized criminal groups make in this field is so large that it sometimes surpasses the annual budget income of small and medium developed European countries. Drug abuse is one of the most organized and most sophisticated crimes today, which involves the activities of professional criminals and specialists. Part of that "dirty" money is often invested in corruptive practices aimed at bribing state functionaries and overthrowing democratically elected governments.

For these reasons, all countries assign substantial resources to combat this harmful phenomenon by establishing adequate health, social, educational systems and especially criminal justice systems, aimed at preventing and suppressing the illicit use, production and trafficking of narcotics. Given the fact that criminal groups often operate in more than one country, huge amounts of money are allocated for the purpose of establishing the police and judicial cooperation at the international level.

The problem of psychotic substances abuse has been monitored, studied and analyzed for a long time in many researches from different aspects. Still, there are many dilemmas, unsolved and open issues left to be considered and scrutinized in the future.

\section{CONCEPT AND CLASSIFICATION OF PSYCHOACTIVE SUBSTANCES}

On the basis of the Psychoactive Substances Act, ${ }^{1}$ a psychoactive substance (PAS) is a chemical substance which, being ingested, changes the psychic structure of the consumer, affecting his/her mood, thinking and behavior. These substances include alcohol, nicotine, various medications, and illegal substances which are discussed in this paper. Those are illegal narcotics whose production and use are not in accordance with the social norms; thus, they are prohibited and sanctioned. The most important psychoactive substances leading to many mental and behavioral disorders, as well as physical and mental addiction, are narcotic drugs (narcotics), whose production and trafficking are prohibited by law.

In 1974, the UN World Health Organization (WHO) defined narcotics as substances that, being ingested by a living organism, can modify one or more of its functions, and having been re-ingested, can lead to physical or mental addiction. ${ }^{2}$

A great number of narcotics and psychoactive substances (PAS) are known to exist, and they are classified according to different criteria. The basic division is according to their origin; thus, the narcotics and psychoactive substances can be classified into two groups: natural and synthetic drugs. According to the criterion of their impact on the society, social acceptability and regulation, the narcotics and psychoactive substances can be classified as legal and illegal. The most significant division is the one based on their effect on the central nervous system, and the way of consumption, where we can differentiate among four major groups: depressors, stimulants, hallucinogens, and cannabinoids (Ćirić, Dimitrijević, 2009: 78).

Depressors - These substances produce their effect by decreasing the neural activity, and many of them are used for alleviating distress and anxiety, and for sleep regulation. There are two major groups of these narcotics. Those are: 1) opioids, and 2) sedatives,

\footnotetext{
${ }^{1}$ Psychoactive Substances Act, "Official Gazette RS “, No. 99/2010)

${ }^{2}$ Terminology and Information on Drugs,UNODCCP, New York, 1999.p.64.
} 
hypnotics and anxiolytics (Ćirić et al., 2009: 78). The most significant opioids are morphine and heroin. When it comes to sedatives, hypnotics and anxiolytics, they are vastly used in medicine for obtaining therapeutic effects (alleviating distress and anxiety, sleep regulation, etc.) (Nikolić, 2001: 22).

Stimulants - These substances change the mental activity in a specific way, causing excitement, mood improvement and euphoria. The most significant stimulants are cocaine, amphetamine and phencyclidine.

Hallucinogens - These narcotics lead to disorders in the field of perception, causing illusions and hallucinations (Ćirić, Dimitrijević, 2009: 80) and leading to altered consciousness, increased alertness and depersonalization phenomena. Having ingested the narcotic, a person has completely distorted audio-visual perception of the environment, i.e. the experience of sensory deceptions takes place. The narcotics can be of herbal or synthetic origin (Ćirić et al., 2009: 80), and the most significant ones are LSD, ecstasy, mescaline.

Cannabinoid - This group of psychoactive substances is obtained from the Indian hemp known as Cannabis, which they are named after, and the addiction to this narcotic is called cannabinomania. Marijuana, whose main ingredient is tetrahydrocannabinol (THC), ${ }^{3}$ is obtained from the hemp seed and dried parts of the hemp leaves and stalk; hashish, which is 5 to 8 times stronger than marijuana, is obtained from the mature flowers of the plant.

Narcotics consumption is a great problem in the contemporary world. Research has shown that a great number of young people, especially adolescents, are affected by this problem. Various factors (such as: the living environment, peer pressure, broken family relationships, bad financial conditions, etc.) can make a person start consuming narcotics and psychoactive substances, hoping that it will help them forget all their problems. Narcotics consumption creates both physical and mental addiction. However, their adverse effects are reflected not only on the consumers but also on their families, the immediate surroundings, and the society as a whole.

\section{NARCOTICS-RELATED CRIMINAL OFFENCES IN THE SERBIAN LEGISLATION AND SANCTIONS IMPOSED ON THE PERPETRATORS}

In the Criminal Code of the Republic of Serbia, the offences related to narcotics are envisaged within Chapter 23 (Offences against Public Health), ${ }^{4}$ which includes three criminal offences: 1) Illicit production and trafficking of narcotics (Article 246 CC); 2) Illicit possession of narcotics (Article 246a CC); and 3) Facilitating the use of narcotics (Article 247 CC).

The criminal offence of illicit production and trafficking of narcotics implies the unlawful production, processing, selling or offering for sale, or purchasing, keeping and transporting for sale, or mediation in sale or purchase, or any other illicit marketing of substances or products that are declared narcotics (Article 246 (1) CC). This criminal offence is commonly punishable by a sentence of imprisonment, as well as by imposing the safety measure of forfeiture, which is always imposed along with the proposed imprisonment sentence (Article $108 \mathrm{CC}$ ). For the most aggravated forms of this criminal offence, the term of imprisonment may range from 3 to 15 years. Less serious forms of unlawful production of poppy, hemp

\footnotetext{
${ }^{3}$ Source: www.drugfreeworld.org/drugfacts/marijuana.html, Accessed on 20.09.2016.

${ }^{4}$ The Criminal Code of the Republic of Serbia, Official Gazette RS, No. 85/05, 88/05-corr., 72/09, 111/09, 121/12, 104/13 ( hereinafter : CC)
} 
and other plants (Art 246 (2)) and production, possession and trafficking of materials and substances intended for production of narcotics (Art 24 (6)) are punishable by a term of imprisonment ranging from 6 months to 5 years. A minimum of 10 years of imprisonment is prescribed for offences (described in paragraph 1) which are committed by an organized criminal group (Article 246(4)). The sentence for this criminal offence can also be the driving license forfeiture which is imposed on the offender who used a vehicle in the preparation or perpetration of this criminal offence.

Article 246a of the Criminal Code of the Republic of Serbia regulates the criminal offence of illicit possession of a small quantity of substance or products for personal consumption which are declared to be narcotics. The envisaged punishment for this crime is a fine or a term of imprisonment not exceeding three years (Article 246a(1)). Apart from the safety measure of forfeiture (Article 246a(3), the perpetrator (addict) may also be imposed the measure of compulsory medical treatment (Articles 83 para.1 and 106 $\mathrm{CC}$ ). The law also envisages the possibility of remitting the punishment of addicts who disclose who they purchase the narcotics from (Article 246a (2)).

The criminal offence of facilitating the use of narcotics (Article 247 CC) can be committed by taking one of the following alternative actions: 1) inducing or enabling another person to take narcotics; 2) giving the narcotics to an individual for his/her own use or use by another individual; 3) making some premises available for the use of narcotics; and 4) otherwise enabling another person to take or enjoy narcotics. This criminal offence is punishable by a term of imprisonment ranging from six months to five years (Article 247 (1)). However, if the offence is committed against a juvenile or several persons, or has resulted in particularly serious consequences, the envisaged punishment is a term of imprisonment from 2 to 10 years (Article 247 (2). The most severe punishment is a term of imprisonment from 3 to 15 years which is imposed for the offence resulting in death of a juvenile or another person (Article 247 (3).

\section{SAFETY MEASURES}

For the criminal offence related to drug abuse, the competent court may order a number of safety/security measures which are imposed under the conditions stipulated in the Serbian Criminal Code (CC) and the Criminal Procedure Code (CPC). The envisaged safety measures include: compulsory treatment of an addict in a relevant institution (Article $83 \mathrm{CC}$ ) and forfeiture (Article $87 \mathrm{CC}$ ). The court shall order compulsory treatment to the offender who has committed an offence due to his/her addiction to narcotics, and where there is a serious danger that the perpetrator will continue committing offences due to this addiction (Article 83 (1) CC). The security measure of compulsory treatment of a drug addict may be carried out in a penitentiary institution or a relevant medical or other specialized institution, and it shall last as long as there is the need for such treatment, but not longer than three years (Article 83 (2) CC). If this measure is ordered along with a sentence of imprisonment, it can last longer than the imposed term of imprisonment but its overall duration shall not exceed three years (Article 83 (3) CC). The time spent in the institution for treatment is included in the imposed imprisonment sentence (Article 83 (4) $\mathrm{CC}$ ). If the safety measure is imposed along with a fine, a suspended sentence, a judicial admonition or discharge from the imposed sentence, it shall be put into effect outside the institution, and it shall not exceed three years (Article 83 (5) CC). 
The safety measure of forfeiture entails the seizure of an object which was used or intended to be used in the commission of a criminal offence, or resulted thereof, where there is a danger that the particular object will be reused for committing a criminal offence, or where the forfeiture is necessary in the interest of public safety or morality (Article 87 (1) CC). This safety measure may entail a mandatory seizure of objects and/or their mandatory destruction (Article 87 (3) CC). For safety reasons, the forfeited narcotics are stored on the premises of the Ministry of Internal Affairs rather than on the court premises. All types of the narcotics are forfeited, but primarily marijuana, hashish, heroin, cocaine, ecstasy, as well as some other synthetic drugs (Nikolić, 2001: 350).

\section{RESEARCH RESULTS}

\section{The significance and the objective of the research}

The main objective of this research is to obtain theoretical and empirical information about the effects of illegal production and trafficking of natural and synthetic narcotics on the epidemic-pandemic scale of their consumption, as well as the impact of these criminal offences on the overall safety both locally and globally, with the ultimate purpose of determining the causes and circumstances leading to the emergence and spreading of illegal production and trafficking of narcotics and psychoactive substances (PAS).

The research was carried out in order to determine how many final judgments were rendered by the High Court in Niš within the observed period of time, what types of criminal sanctions were imposed, what offences related to trafficking in narcotics are the most prominent, and how they were committed.

\section{Research methods}

In the course of research and subsequent drafting of this paper, qualitative methods have been used, including the methods of examining individual cases and conducting content analysis upon insight into the records and final judgments of the High Court in Niš, as well as the quantitative methods, including statistical analysis and data analysis on the criminal sanctions imposed on the perpetrators of narcotics-related criminal offences (envisaged in Article 246, 246a and 247 of the Serbian Criminal Code), in accordance with the research time frame.

\section{Research hypotheses}

Having analyzed and studied many cases from theory and practice, the researcher has set the following hypotheses which have been verified by the research:

- The number of criminal offenses related to narcotics is increasing year after year;

- These offences are most frequently committed by men;

- The perpetrators are mainly younger people, up to the age of 30 ;

- Criminal offences related to narcotics are mostly carried out in complicity;

- The most commonly traded narcotics are marijuana and heroin;

- The safety measures, particularly the compulsory treatment and forfeiture measures, are imposed on the perpetrators;

- The perpetrators are not necessarily the consumers of narcotics; 
- Suspended sentence may not be imposed for the criminal offence envisaged in Article 246(1) CC of the Republic of Serbia;

- The penalty policy is strict, as it is not possible to mitigate a sentence, and the most severe punishment under Article 246(1) CC is 12 years' imprisonment;

- In most cases, women act as accomplices.

The research was carried out at the High Court in Niš in July-September 2016, covering the period from 2013 to 2015 . It entailed perusing the court registers for the perpetrators of the criminal offences envisaged in Article 246(1) of the Serbian Criminal Code (CC), Article 246a(1) CC (re-qualified by the High Court in compliance the indictment of the High Public Prosecutor's Office), and Article 247(1) CC, for the purpose of collecting statistical data on the perpetrators of these criminal offences, their age and gender, the type of sentences imposed on the offenders during the observed time frame, and the safety measures imposed on the offenders in the territory covered by the jurisdiction of the High Court in Niš.

In the period from 2013 to 2015, the High Court in Niš imposed a total number of 407 convictions for the criminal offence of illicit production and trafficking of narcotics (Article 246(1) CC), a total of 175 convictions for the illicit possession of narcotics (Article 246a(1) CC), which was re-qualified by the High Court in Niš in line with the indictment of the High Public Prosecutor Office, and a total of 22 convictions for the criminal offence of facilitating the use of narcotics (Article 247(1) CC), as the least frequent narcotics-related offence (Table 1).

Table 1 The total number of convictions imposed by the High Court in Nis in 2013, 2014 and 2015 for the criminal offence of illicit production and trafficking of narcotics (Article 246(1) CC), the criminal offence of illicit possession of narcotics (Article 246a(1) CC)., and the criminal offence of facilitating the use of narcotics (Article 247(1) CC)

\begin{tabular}{lccc}
\hline $\begin{array}{l}\text { Criminal } \\
\text { offence }\end{array}$ & $\begin{array}{c}\text { Illicit production and } \\
\text { trafficking of narcotics }\end{array}$ & $\begin{array}{c}\text { Illicit possession of } \\
\text { narcotics }\end{array}$ & $\begin{array}{c}\text { Facilitating the use of } \\
\text { narcotics }\end{array}$ \\
\hline Year 2013 & 143 & 58 & 6 \\
Year 2014 & 109 & 52 & 5 \\
Year 2015 & 155 & 65 & 11 \\
\hline
\end{tabular}

The hypothesis that the number of criminal offences is increasing year after year can be deemed absolutely plausible, which is verified by the data provided in Table 1 . By observing the data it could be noticed that, on the basis of the imposed convictions, the number of the criminal offences related to narcotics is increasing year after year. Thus, the greatest number of the convictions was imposed in the year 2015, including 155 convictions for the criminal offence of illicit production and trafficking of narcotics (Article 246(1) CC), 65 convictions for the illicit possession of narcotics (Article 246a(1) $\mathrm{CC}$ ), and 11 convictions for the criminal offence of facilitating the use of narcotics (Article 247(1) CC). The fewest number of convictions were imposed in 2014 for the criminal offence of facilitating the use of the narcotics. However, it could be noticed that the number of convictions in 2014 is smaller than in 2013, the reason for this being the attorneys' strike from 17 September 2014 until 26 January 2015, when the Court did not render judicial decisions. 
Table 2 The number of male and female offenders who committed the offences envisaged in Articles 246(1), 246a(1) and 247(1) of the Serbian Criminal Code in 2013,2014 and 2015.

\begin{tabular}{lcccccc}
\hline $\begin{array}{l}\text { Criminal } \\
\text { offence }\end{array}$ & $\begin{array}{c}\text { Illicit production and } \\
\text { trafficking of narcotics } \\
\text { Illicit possession of narcotics }\end{array}$ & $\begin{array}{c}\text { Illicit possession of } \\
\text { narcotics }\end{array}$ & $\begin{array}{c}\text { Facilitating the use of } \\
\text { narcotics }\end{array}$ \\
\hline Year & $\begin{array}{c}\text { Number of } \\
\text { male } \\
\text { offenders }\end{array}$ & $\begin{array}{c}\text { Number of } \\
\text { female } \\
\text { offenders }\end{array}$ & $\begin{array}{c}\text { Number of } \\
\text { male } \\
\text { offenders }\end{array}$ & $\begin{array}{c}\text { Number of } \\
\text { female } \\
\text { offenders }\end{array}$ & $\begin{array}{c}\text { Number of } \\
\text { male } \\
\text { offenders }\end{array}$ & $\begin{array}{c}\text { Number of } \\
\text { female } \\
\text { offenders }\end{array}$ \\
\hline 2013 & 135 & 8 & 54 & 4 & 6 & $/$ \\
2014 & 103 & 6 & 49 & 3 & 5 & $/$ \\
2015 & 144 & 11 & 58 & 7 & 10 & 1 \\
\hline
\end{tabular}

The second hypothesis that the perpetrators are mostly men is verified by the data provided in Table 2, containing the number of cases where the perpetrators were men and women, respectively. The difference is striking since women were perpetrators only in 3 - 5\% of cases, whereas there were no recorded female perpetrators of the criminal offence of facilitating the use of narcotics in 2013 and 2014. In 2015, only one woman was recorded as the perpetrator of this offence (Article 247(1) CC). The largest number of female offenders (11 in total) was recorded in 2015 as the perpetrators of the criminal offence of illicit production and trafficking of narcotics (Article 246(1) CC); the largest number of female offenders of illicit possession of narcotics (Article 246a(1) CC) was recorded in 2015 as well. It may be concluded that the number of female offenders is increasing along with the number of criminal offences.

Table 3 The number of perpetrators under the age of 30 who committed the offences envisaged in Articles 246(1), 246a(1) and 247(1) of the Serbian Criminal Code in 2013, 2014 and 2015.

\begin{tabular}{lccc}
\hline $\begin{array}{l}\text { Criminal } \\
\text { offence }\end{array}$ & $\begin{array}{c}\text { Illicit production and } \\
\text { trafficking of narcotics }\end{array}$ & $\begin{array}{c}\text { Illicit possession of } \\
\text { the narcotics }\end{array}$ & $\begin{array}{c}\text { Offence of making use } \\
\text { of the narcotics }\end{array}$ \\
\hline Year 2013 & 77 & 32 & 2 \\
Year 2014 & 65 & 36 & 3 \\
Year 2015 & 92 & 40 & 5 \\
\hline
\end{tabular}

The third hypothesis that the largest number of offenders are under the age of 30 may also be deemed plausible as the data in Table 3 suggest that more than half of the perpetrators of the narcotics-related criminal offences were under the age of 30 . From the total number of 407 convictions imposed for the commission of the criminal offence of illicit production and trafficking of narcotics (Article 246(1) CC), a total of 234 convictions were imposed on persons under the age of 30; from the total of 175 convictions related to the criminal offence of the illicit possession of narcotics (Article 246a(1) CC), a total of 108 were imposed on persons under the age of 30; finally, from the total number of 22 convictions related to the criminal offence of facilitating the use of narcotics (Article 247(1) CC), a total of 10 convictions were imposed on persons under the age of 30. As previously noted, all this confirms that drug addiction is a serious and almost unsolvable issue which mostly affects children, young people and adolescents. 
Table 4 The number of offences committed in complicity, per year and per criminal offence

\begin{tabular}{lccc}
\hline $\begin{array}{l}\text { Criminal } \\
\text { offence }\end{array}$ & $\begin{array}{c}\text { Illicit production and } \\
\text { trafficking of narcotics }\end{array}$ & $\begin{array}{c}\text { Illicit possession } \\
\text { of narcotics }\end{array}$ & $\begin{array}{c}\text { Facilitating the use } \\
\text { of narcotics }\end{array}$ \\
\hline Year 2013 & 45 & 10 & 5 \\
Year 2014 & 32 & 9 & 1 \\
Year 2015 & 63 & 18 & 4 \\
\hline
\end{tabular}

The next hypothesis that the criminal offences related to narcotics are commonly carried out in complicity could be deemed plausible, on the basis of the data provided in Table 4. The complicity is especially characteristic for the criminal offence of facilitating the use of narcotics, given the fact that the offence was committed in complicity in 10 out of 22 cases. However, in 2015, the criminal offence of illicit production and trafficking of narcotics (Article 246 (1) CC) was committed in complicity in 63 cases out of the total number of 155 convictions, whereas the criminal offence of illicit possession of narcotics (Article 246a (1) CC), was carried out in complicity in 18 cases out of the total number of 65 convictions. In the entire period from 2013 to 2015, the criminal offence of illicit production and trafficking of narcotics (Article 246(1) CC) was carried out in complicity in 140 cases out of the total number of 407 convictions.

Table 5 The total number of convictions per criminal offence, involving marijuana, heroin and other narcotic in 2013, 2014 and 2015.

\begin{tabular}{lccccccccc}
\hline $\begin{array}{l}\text { Criminal } \\
\text { offence }\end{array}$ & \multicolumn{2}{c}{$\begin{array}{l}\text { Illicit production and } \\
\text { trafficking of narcotics }\end{array}$} & \multicolumn{2}{c}{$\begin{array}{c}\text { Illicit possession } \\
\text { of narcotics }\end{array}$} & \multicolumn{2}{c}{$\begin{array}{c}\text { Facilitating the use } \\
\text { of narcotics }\end{array}$} \\
\hline Year & Marijuana Heroin & $\begin{array}{c}\text { Other } \\
\text { narcotics }\end{array}$ & Marijuana Heroin & $\begin{array}{c}\text { Other } \\
\text { narcotics }\end{array}$ & Marijuana Heroin & $\begin{array}{c}\text { Other } \\
\text { narcotics }\end{array}$ \\
\hline Year 2013 & 68 & 54 & 21 & 25 & 24 & 9 & 3 & 2 & 1 \\
Year 2014 & 42 & 35 & 17 & 28 & 14 & 10 & 4 & 1 & $/$ \\
Year 2015 & 85 & 41 & 29 & 35 & 23 & 7 & 5 & 3 & 3 \\
\hline
\end{tabular}

The data provided in Table 5 verify the hypothesis that the most common narcotics are marijuana and heroin, while others narcotics are much less common and appear either along with marijuana and heroin or other narcotics. Marijuana takes the top position, primarily due its simple production and availability. In the entire observed period (20132015), marijuana was listed in as many as 195 convictions pertaining to the criminal offence envisaged in Article 246(1) CC, which means that almost half of the convictions were imposed for illicit production and trafficking of marijuana. The increase in the trafficking and possession of marijuana was especially notable in 2015. In the entire observe period (2013-2015), marijuana was the issue in a total number of 88 cases involving the criminal offence of the illicit possession of narcotics (Article 246a (1) CC), which again shows that marijuana prevails in $50 \%$ of convictions. Marijuana is also a predominant narcotic in the criminal offence of facilitating the use the narcotics (Article 247(1) CC), whereas the number of recorded case involving heroin, amphetamines and other narcotics was considerably lower in all three criminal offences. 
Table 6 The total number of convictions including the imposed safety measures: forfeiture and compulsory treatment in 2013, 2014 and 2015

\begin{tabular}{lcccccc}
\hline $\begin{array}{l}\text { Criminal } \\
\text { offence }\end{array}$ & \multicolumn{2}{c}{$\begin{array}{c}\text { Illicit production and } \\
\text { trafficking of narcotics }\end{array}$} & $\begin{array}{c}\text { Illicit possession } \\
\text { of narcotics }\end{array}$ & $\begin{array}{c}\text { Facilitating the use } \\
\text { of narcotics }\end{array}$ \\
\hline Year & $\begin{array}{c}\text { Forfeiture } \\
\text { measure }\end{array}$ & $\begin{array}{c}\text { Compulsory } \\
\text { treatment } \\
\text { measures }\end{array}$ & $\begin{array}{c}\text { Forfeiture } \\
\text { measure }\end{array}$ & $\begin{array}{c}\text { Compulsory } \\
\text { treatment } \\
\text { measures }\end{array}$ & $\begin{array}{c}\text { Forfeiture } \\
\text { measure }\end{array}$ & $\begin{array}{c}\text { Compulsory } \\
\text { treatment } \\
\text { measures }\end{array}$ \\
\hline Year 2013 & 143 & 15 & 58 & 19 & 6 & $/$ \\
Year 2014 & 109 & 18 & 52 & 17 & 5 & $/$ \\
Year 2015 & 155 & 24 & 65 & 28 & 11 & $/$ \\
\hline
\end{tabular}

On the basis of data provided in Table 6, we can conclude that the perpetrators of narcotics-related criminal offences are imposed safety measures, such as forfeiture and compulsory treatment, which implies that the set hypothesis may be deemed absolutely plausible. Namely, the forfeiture measure includes the forfeiture of an object used or intended for the criminal offence; on the basis of the collected data, it could be concluded that the Higher Court in Nis imposes this measure in every single case, regardless of the offence, perpetrator and narcotics. Thus, the measure of forfeiture is compulsory for the criminal offences related to narcotics. When it comes to the measure of compulsory treatment of an addict, it may be imposed on the perpetrators of all criminal offences related to narcotics but, in particular, it is often imposed on drug addicts for the criminal offence of illicit possession of narcotics. In the entire observed period (2013-2015), the Court proposed compulsory treatment measures in 64 cases out of the total number of 175 convictions for the criminal offence of illicit possession of narcotics (Article 246a(1) CC). It is interesting that, in all three years, the Court did not impose any compulsory treatment measures on the perpetrators of the criminal offence of facilitating the use of narcotics (Article 247(1) CC). As for the criminal offence of illicit possession and trafficking of narcotics (Article 246(1) CC), the largest number of compulsory treatment measures was proposed in 2015.

The hypothesis that the perpetrators of these criminal offences are not necessarily the consumers of narcotics may also be deemed plausible, especially when it comes to the offence of the illicit production and trafficking of narcotics. Namely, out of 407 convictions for the criminal offence envisaged in Article 246(1) CC, only 29 perpetrators admitted that they consumed narcotics. The situation is slightly different when it comes to the criminal offence of illicit possession of narcotics (Article 246a (1) CC), where 78 perpetrators out of 175 convictions in total confirmed that they used narcotics for their own needs.

On the basis of the collected data, the hypothesis that a suspended sentence could not be imposed on the perpetrators of the criminal offence of illicit production and trafficking of narcotics (Article 246(1) CC) is absolutely plausible, considering that in the observed period there were no recorded cases in which the Court imposed the suspended sentence. The Court only imposed a sentence of imprisonment, or a prison sentence in combination with a fine.

The hypothesis that the penalty policy is strict, as it is not possible to mitigate the sentence, may be deemed plausible because there were no recorded cases of mitigating the sentence in the observed period. When it comes to the hypothesis that the most severe sentence is the imprisonment of up to 12 years, the findings show that the Court imposed the sentence of up to 5 years' imprisonment in $70 \%$ of cases involving the criminal offence of illicit production and trafficking of narcotics envisaged in Article 246 (1) CC. In the 
observed period (2013-2015), there were no recorded cases of 12 years' imprisonment, which is the maximum sentence for the commission of criminal offences related to narcotics.

Table 7 The total number of cases (in 2013, 2014 and 2015) where women acted as accomplices

\begin{tabular}{lccc}
\hline $\begin{array}{l}\text { Criminal } \\
\text { offence }\end{array}$ & $\begin{array}{c}\text { Illicit production and } \\
\text { trafficking of narcotics }\end{array}$ & $\begin{array}{c}\text { Illicit possession } \\
\text { of narcotics }\end{array}$ & $\begin{array}{c}\text { Facilitating the use of } \\
\text { narcotics }\end{array}$ \\
\hline Year 2013 & 47 & 18 & 3 \\
Year 2014 & 47 & & \\
Year 2015 & & & 3 \\
\hline
\end{tabular}

The hypothesis that women mostly appear as accomplices may also be deemed plausible. On the basis of collected data, provided in Table 7, women were accomplices in 47 cases out of 407 convictions for the criminal offence of illicit production and trafficking of narcotics envisaged in Article 246 (1) CC; women were accomplices in 18 cases out of 175 convictions for the criminal offence of illicit possession of narcotics envisaged in Article 246a(1) CC; finally, women were accomplices in 3 cases out of 22 convictions for the criminal offence of facilitating the use of narcotics envisaged in Article 247 (1) CC. On the whole, the number of cases in which women act as accomplices exceeds the number of cases where they are perpetrators, which confirms this hypothesis.

\section{CONCLUSION}

The research data suggest that the number of perpetrators of criminal offenses related to narcotics is constantly on the rise. This trend has an adverse affect not only on individual drug consumers but also on society as a whole. In particular, it is highly disconcerting that the largest number of consumers and drug dealers are children and young people under the age of 30. Therefore, it is crucial to give special attention to the detection of narcoticsrelated crimes and their perpetrators. One of the essential conditions for achieving this objective and combating these crimes is collaboration between government authorities, and engagement of the police and all national security structures. Another important condition is international cooperation, given the fact that trafficking in narcotics is a transnational crime. In order to detect organized criminal groups and individuals involved in drug-trafficking, it is vital to use all necessary mechanisms, undertake special investigative actions, and apply special crime prevention methods and tactics, ultimately aimed at counteracting these crimes and decreasing the number of offenses. In case a crime has already been committed, courts shall deliberate on the issue by examining the merits of each case and imposing proper individual punishment, aimed at achieving the intended purpose of punishment. In sentencing, courts should impose more severe sanctions for the commission of these crimes, given that more lenient sentences eventually result in increasing crime rate.

The presented complexity of drug-related crimes points to a huge problem that may affect and undermine any country in the world. Therefore, in times to come, the global civilization system will have to address these challenges and resolve all open issues related to this multifaceted problem. 


\section{REFERENCES}

Ćirić, Z., Dimitrijević, B. Osnovi sudske psihijatrije i sudske psihologije (Fundamentals of Forensic Psychiatry and Forensic Psychology), Studentski kulturni centar, Niš, 2009.

Krivični zakonik Republike Srbije (The Criminal Code of the Republic of Serbia), Službeni glasnik Republike Srbije, br. 85/05, 88/05-ispr., 72/09, 111/09, 121/12, 104/13.

Nikolić, D., Narkomanija-zločin ili kazna (Drug Addiction: crime or punishment), Srpsko udruženje za krivično pravo, Beograd, 2001.

Terminology and Information on Drugs, UNODCCP, New York, 1999, p.64.

Zakon o psihoaktivnim supstancama (Psychoactive Substances Act), Službeni glasnik Republike Srbije, br, 99/2010

Foundation for a drug-free world: What is marijuana? www.drugfreeworld.org/drugfacts/marijuana.html, Accessed 20.09.2016

\section{TRGOVINA PSIHOAKTIVNIM SUPSTANCAMA}

Rad obuhvata rezultate istraživanja koje je sprovedeno u Višem sudu u Nišsu, a koje obuhvata period od 01.01.2013. godine do 01.01.2016. godine. Na osnovu statističkih podataka utvrđeno je koliko je doneto pravnosnažnih presuda za određeni vremenski period, za svako od navedenih krivičnih dela. Zatim utvrđeno je da se broj krivičnih dela u vezi sa opojnom drogom, povećava iz godine u godinu, što je dokaz da zloupotreba psihoaktivnih supstanci predstavlja nerešiv problem, kao i da se kao najčešći izvršioci javljaju muškarci, mlađe starosne dobi, dok se žene češće javljaju kao saučesnici u izvršenju ovih krivičnih dela. Istraživanje je usmereno i na utvrđivanje broja presuda koje su izrečene za krivična dela izvršsena u saizvršilaštvu, kao i na otkrivanju najzastupljenijih opojnih droga, gde preovlađuje opojna droga marihuana. Takođe je istraživanje usmereno i na kaznenu politiku krivičnih dela u vezi sa opojnim drogama, kao i merama bezbednosti koje se izriču učiniocima.

Ključne reči: opojna droga, žene saučesnice, saizvršilaštvo, mere bezbednosti, kaznena politika

Proofreading and translation: Gordana Ignjatović 